\title{
Language Acquisition of Three Years Old Twin at Sentence Level
}

\author{
Min Adlina ${ }^{1}$, Sri Permana Dewi ${ }^{2}$, Zhana Sabrina Amelia ${ }^{3}$ \\ \{minadlinaa@gmail.com¹,permanadewi31@gmail.com ${ }^{2}$, zhanasabrina10@gmail.com³ \\ Universitas Sumatera Utara, Medan, Indonesia
}

\begin{abstract}
This study was entitled First Language Acquisition of three years old twin at sentence level. This is one branch of psycholinguistics that learns about language acquisition. Especially at the sentence level for Indonesian children aged three years in producing speech. This study used descriptive qualitative method. The author took data from the speech recordings delivered by two three-year-old twins named Azzahra and Azzura. In analyzing data, the author uses the language theory of milestones from infants to childhood by C.B. Kopp. Based on data analysis and explanation, the author suggests that not all Kopp theories are applied in the words of the subject. There are eight of the nine characteristics applied to the words of the subject. At the end of the study, the authors also found differences between the two subjects who had different levels of vocabulary acquisition.
\end{abstract}

Keywords: Language acquisition, Sentence level, Three years old twin

\section{Introduction}

When people want to talk to another, they will use language. Language is essential to every aspect and interaction in life. We use language to inform people around us about what we feel, what we desire, and what we ask. We communicate effectively with our words, gestures and tone of voice in multitude of situation. Language is a meaningful and articulated sound symbol system (produced by utterance) which is arbitrary and conventional in nature, which is used as a means of communication by a group of people to give birth to feelings and thoughts [1]. Almost in line with Wibowo's opinion, Walija revealed the definition of language is the most complete and effective communication to convey ideas, messages, intentions, feelings and opinions to others [2].

As children learn to talk, they go through a series of stages, beginning with infancy, when they are unable to converse and do not yet understand any language. They go from babbling at seven to ten months old, to producing their first recognizable words six to twelve months later. Then, within a few months, they combine words and gestures, and produce their first 
word combinations around age two. This is followed by the production of ever more complex, adult like utterances, as they become active participants in conversation. At age three, they begin to use language for a larger array of functions- telling stories, explaining how a toy works, persuading a friend to do something, or giving someone directions for how to get somewhere. In acquiring language, the goal is to become a member of a community of speakers. This entails learning all the elements of a language, both structure and usage. Children need to learn the sound system called phonology. They need to learn about the structure of words, called morphology. And they don't use one word at a time. They combine them, and again the possible sequences of words in language have to be learnt, called syntax. This research is focused on three years old children. Crystal stated that in this age, children start asking lots of different questions signaling at the same time with a marked intonation.By this stage, children begin to make and express more complex sentences but still simple ones. Many experts consider that syntactic acquisition starts when a child can combine two or more words [3]. Therefore, they consider that holophrastic stage is not related to the syntactic acquisition. In this research, the writer chooses twin as the subjects. They are Annisa Azzahra and Annisa Azzura. They are the first children in their family. They were born on 18 February 2012. They are active children and talkative in their age. They seldom play outside with other friends. They just play with their own sister.

In analyzing and explaining the research, the writer uses first language acquisition and child language development. By age 3, grammar and syntax are fairly well developed. Early speech is characterized by simplification, underextending and overextending word meanings, and overregularizing rules [4]. In sentence structure, children can speak in four to six word sentences, 300 word vocabulary, engages in simple conversation, memorizes and repeats simple rhymes, songs or finger plays, understands sentences and questions as indicated by a relevant response, and describes action in pictures.

\section{Methodology}

In writing this research, the writer applied field research and library research, that is by adapting some theories and information about language acquisition from books, thesis, internet and other sources and also did an observation of the object of the research. This research is focused on sentence structure acquired by twin of three years old based on the first language acquisition which is Bahasa Indonesia. The writer chooses qualitative method in the research.

The quantitative method is a scientific approach that looks at reality that can be classified: concrete, observable and measured [5]. Variables that are related to one another so that it causes cause and effect, where research data in the form of numbers and statistics use analysis. Qualitative researchers tend to use inductive data analysis, meaning that important themes emerge from the data [6]. Descriptive qualitative method is one that uses to create even or collect basic data [7].

As the writer knows that qualitative method is a broad methodological approach that encompasses many research methods. The aim of qualitative research may vary with the disciplinary background, such as a psychologist seeking to gather an in-depth understanding 
of human behaviour and the reasons that govern such behaviour. Qualitative methods examine the why and how of decision making, not just what, where, when, or who.

The source of this research is three years old twin, named Annisa Azzahra and Annisa Azzura. The writer chooses these twin because the writer wants to know whether they have differences in acquiring their first language acquisition especially on sentence structure. Data are in the form sentence structure produced by the twin. They are from the same background and live together with their family. The data of this research is acquired from naturalistic observation method by testing the truth of theory without manipulating the conversation. The writer uses iphone 5 as the equipment to collect the data. The observation was done in one month, two times in a week. Every conversations will be recorded by mobile phone (iphone 5). Not only recording, but also writing the words that the objects uttered.

1. The writer records all the conversations between the twin.

2. The writer rewrites the sentences which have been collected from the mobile phone.

3. The writer lists the utterances of the twin.

4. The writer divides all the sentences which are produced based on the Kopp's theory .

5. The writer compares the aquisition between subjects in acquiring sentences.

The results of the data analysis in this research will be done after the reduction activities namely transcription, selection, classification of data recording has completed. The analysis is done in a month and it is done two times in a week along with data collection. In one meeting, it takes about two until three hours to collect the data. Next, data arranged systematically. The data research is analyzed qualitatively, the results of data analysis starts with identifying and classifying speech into sentence structure based on Kopp's Theory.

\section{Result and Discussion}

Based on the research that the writer has done on twin of three years old using Kopp's Theory, the writer found that twin at 3 years old have some characteristics in acquiring language especially at sentence structure.

\subsubsection{Using yes/no questions}

Yes/no questions usually used to ask something that only need two answers, they are yes or no. In Bahasa, question word that usuals used are apa, apakah or form of sentences or words that need an answer yes or no.

Based on the research, the writer finds:

Azzahra ( Object 1)

Dialogue A:

Bunda: adek gak makan? [ade?] [ga?] [makan] ? "don't you eat, sister?"

Zahra : makan apa? [makan] [apa] ? "eat what?" 
Bunda : makan nasi, gak makan? [makan] [nasi], [ga?] [makan] ? "eat rice, don't you?"

Zura : makan! [makan]! "Eat!"

Zahra : makan! [makan]! "Eat!"

Bunda : kak aya gak makan? [ka?] [aya] [ga?] [makan] ? "don't you eat, kak aya?"

Zahra : ada ikan? [ada] [ikan]? "is there any fish?"

Bunda : ada. [ada] "yes, there is"

This conversation was happening when their mother wanted to feed them. And their mother asked whether they wanted to eat or not. And Azzahra asked her mother whether there was fish or not.

Dialogue B:

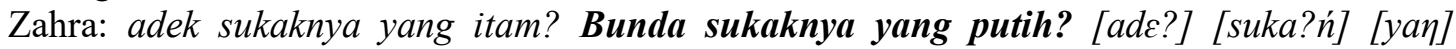
[itam]? [bunda suka?ń] [yaף] [putih]? "does adek like black? Does bunda like white?"

Bunda: gak suka [ga?] [suka] "I don't like it"

The dialogue happened when they were playing and colouring. And Azzahra asked her mom which colour that her younger sister and her mom like.

Azzura ( Object 2)

Dialogue A:

Zahra : jangan, ini motor. [jaqan], [ini] [motor] "no, this is motorcycle"

Zura : motol? [motol]? "is this motorcycle?"

Zahra : iya, bremm bremm.. [iya] [bramm bramm] "yes, bremm bremm."

Zura : alhamdulillah.. [alhamdulillah] "thank God"

Ni talinya?[ni] [talin'] ? "is this the rope?"

Zahra : iya. [iya] "yes"

This conversation was happening when they were playing together. And Azzura asked her older sister the thing that they played.

Dialogue B:

Zura: belum, ini masi nampak. [belum], [ini] [masi] [nampa?] "not yet, it seems appear"

Ini bisa masuk?[ini] [bisa][masu?] ? "can it get in?"

Rasyid: bisa. [bisa] "yes, it can"

The dialogue took place when Azzura was playing with her cousin named Rasyid. And she asked if the toys could get in or not.

The dialogue between mother and Azzahra and Azzura with Azzahra and Azzura with her cousin shows that the twin are able to use question words and other form of sentence to form interrogative sentence which need yes or no answer.

\subsubsection{Using why questions}

At 3 years old, the curiousity of a child usually increases. They always want to know what things that they see and they usually ask someone around them. In Bahasa, question word that usually used in expressing this situation is mengapa,kenapa. It usually need some explanation or the reason.

Azzahra ( Object 1)

Dialogue A:

Zahra: kenapa orangnya?[kənapa] [oranń] ? "what happen to the person?" 
Zura: napa olangnya? Uti, kenapa olangnya (orangnya)? Bedalah(berdarah) ? [napa]

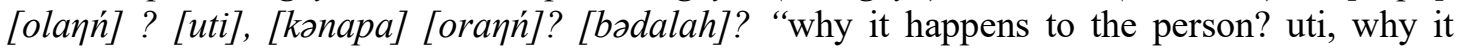
happens? bleeding?"

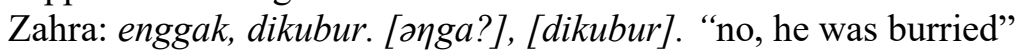

This conversation took place when they watched the television and saw that there was someone bleeding.

Dialogue B:

Zahra: bunda, kenapa gak sekolah? [bunda], [kənapa] [ga?] [səkolah] ? "bunda, why I don't go to school?"

Bunda: tapi kak aya masih sakit [tapi] [ka?] [aya] [masih] [sakit] "you are still sick"

Zahra: iya, badan kak aya masih panas [iya], [badan] [ka?] [aya] [masih] [panas] "yes, my body is still warm"

The dialogue took place when Azzahra asked her mother why she didnot go to school. And her mother said that she was sick.

Azzura (Object 2)

Dialogue A:

Zura: uti, kenapa ini? Copot? [uti], [konapa] [ini]? [copot]? "uti, why is it? Is it broken?"

Zahra: uti, ini kok gak dimakan? [uti], [ko?] [ga?] [dimakan]? "uti, why don't you eat?"

This conversation took place when Azzura was playing her cupboard. And the pen was broken. So she asked her grandmother why it happened.

Dialogue B:

Bunda: ayok adek bobok udah malem! [ayok?] [ade?] [bobo?] [udah] [malom] "come on, let's go to sleep!"

Zura: kenapa gak makan nasi, bunda?[kanapa] [ga?] [makan] [nasi], [bunda]? "why don't I eat rice, bunda?"

Bunda: tapi tadi udah [tapi] [tadi] [udah] "you have eaten"

The dialogue between Azzahra with Azzura and Azzura with her grandmother ( uti) and Azzura with her mother shows that the twin are able to use why question to get an explanation in responding the question.

\subsubsection{Using negatives sentences}

Negatives sentences is a sentence which is in the main verbal phrase contains negative element or negation. The key word that usually used is tidak, enggak, bukan.

Azzahra (Object 1)

Dialogue A:

Zahra: kak aya nasinya aja. [ka?] [aya] [nasiń] [aja] "kak aya wants rice only"

Zura: ambek nasinya. [ambe?] [nasin'] "take the rice!"

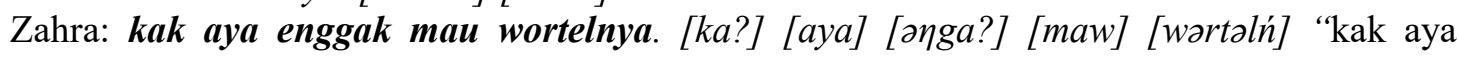
doesn't want carrot" 
This conversation took place when their mother fed them. They were eating rice with soup. But Azzahra said that she did not want to eat carrot.

Dialogue B:

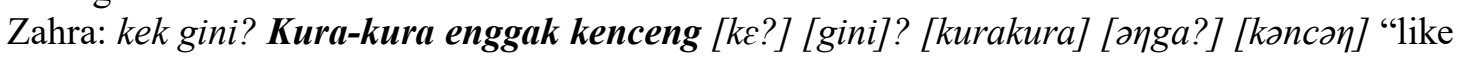
this? Turtle isnot fast"

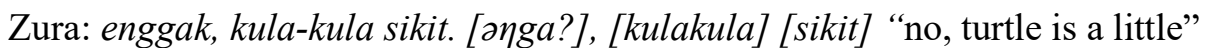

The dialogue is when they were running and they think that they were like turtle.

Azzura ( Object 2)

Dialogue A:

Zura: nanti kak aya pigi sama bunda, tinggal nangis [nanti] [ka?] [aya] [pigi] [sama] [bunda], [tingal] [naiis] "kak aya will go with mom, I will cry"

Zahra: gak takut, gak takut [ga?] [takUt], [ga?] [takUt]" I'm not afraid, I'm not afraid"

Zura: om Satia gak ada [om] [Satiya][ga?] [ada] "Om Satia isnot here"

Kak aya ni enggak mau kongsi [ka?] [aya] [ni] [ga?] [mawu] [konsi] " kak aya doesn't want to share"

This conversation took place when they were playing with kelatak (rubber seeds) but then they quarreled because Azzahra did not want to give Azzura some rubber seeds.

Dialogue B:

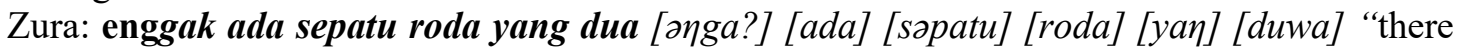
is no two roller skates"

Zahra: ini? Kancing. [ini]? [kancin] "isn't it? Button"

Shila: gak bisa itu [ga?] [bisa] [itu] "It can't"

The dialogue happened when they were trying to play roller skates.

The dialogue above between Azzahra with Azzura shows that the twin are able to use negative sentences to show the negation of their speech.

\subsubsection{Using imperative sentences}

Imperative sentence usually used to say something that needs a response in action.

In the last sentence in imperative sentence usually uses exclamation mark.

Azzahra ( Object 1)

Dialogue A:

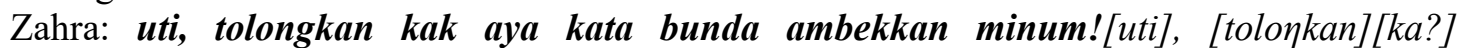
[aya][kata] [bunda] [ambe?kan][minum] "uti, give me some drink please!"

This conversation took place when her mother asked her to bring her some drink, but zahra asked her grandmother to bring it to her.

Dialogue B:

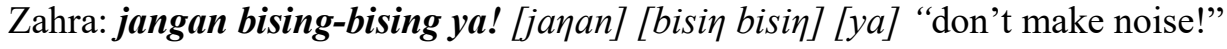

Zura: ya Allah..

The dialogue happened when Azzahra and Azzura were playing together.

Azzura ( Object 2)

Dialogue A: 
Zahra: ini kakak aya punya, ini adek punya semalem [ini] [ka?] [aya] [puń], [ini] [ade?] [puń] [səmalom]" this is mine, this was yours yesterday"

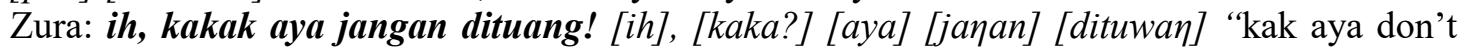
pour it!"

Zahra: maaf.[ma'af] "sorry"

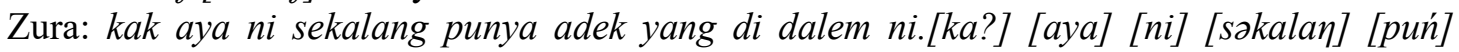
[ade?] [yan] [di] [dalom] [ni] "Now, what thing inside is mine"

The conversation is when they were playing the rubber seeds.

Dialogue B:

Zura: bunda, ambek sampahnya![bunda], [ambe?] [sampahń]! "bunda, grab the rubbish!"

The dialogue above between Azzahra with Azzura shows that the twin are able to use the sentence contains request to or not to do something.

\subsubsection{Embedding one sentence within another using clause}

Clause is a group of related words containing a subject that tells readers what the sentence is about, and a verb that tells readers what the subject is doing. A clause comes in two types. Independent clause and dependent clause. Independent Clause called a main clause, is a clause that can stand on its own. It contains all the information necessary to be a complete sentence. An independent clause has a subject that tells what the sentence is about and a verb that tells what the subject is doing. It expresses a complete thought, relaying that something has happened or was said.

Example: kucing itu menyukai ikan goreng. The subject is kucing, the verb is menyukai and as a reader now knows that kucing itu menyukai ikan goreng, making it a complete thought.

A dependent clause also called a subordinate clause, is a clause that cannot stand on its own because it does not contain all the information necessary to be a complete sentence. A clause is dependent because of the presence of words such as sebelum, sesudah, karena, sejak, walaupun, etc.

Example: kucing menyukai ikan goreng karena rasanya sangat lezat. This sentence contains two clauses. The first is kucing menyukai ikan goreng and the second, karena rasanya sangat lezat. In the first sentence has shown that it is an independent clause because it has the subject that tells what is about. But the second one, there is no subject that tells what is about, it needs other clause to make it clear.

Azzahra ( Object 1):

Dialogue A:

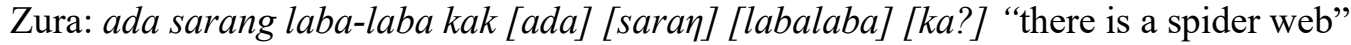
Zahra: kak aya mau kasi makan laba-laba ini [ka?] [aya] [maw][kasi] [makan] [labalaba] [ini] "I want to feed the spider"

The dialogue above shows that Azzahra is able to embed one sentence within another using clause by showing the sentence that she wants to feed the spider. Kak aya as the subject that tells what is about, and ngasi makan is the verb that tells what the subject is doing. 
Dialogue B:

Zahra: ini belum ditarok [ini] [balUm] [ditarO?] "it hasn't been put yet"

Ikan lagi ma [ikan] [lagi] [ma] one more fish"

the door"

Kak aya tutup pintunya dulu ya .[ka/] [aya] [tutUp] [pintUń] [dulu] [ya] "I close

Dialogue C:

Zahra: adek, sini kita main! [ade?], [sini] [kita] [main]! "come on, play here!"

Zura: adek mau main masak-masakan dulu[ade?] [maw] [main] [masa? Masakan]"I want to play cooking"

Zahra: kita bobok di tempat tidur aja dek [kita] [bobo?] [di] [tompat] [tidur] [aja] [de?]

"we sleep on the bed"

Dialogue D:

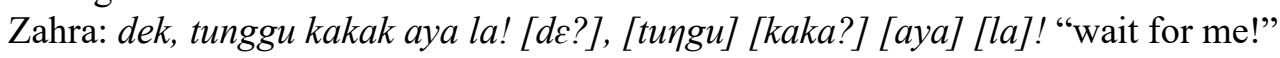
Zura: iya loo adek tungguin ini [iya] [loo] [ade?] [tunguin] [ini] "I'm waiting for you"

Zahra: kita kan mau memasak bersama [kita] [kan] [maw] [məmasa?] [bərsama] "we will cook together"

The dialogue above shows that Azzahra is able to embed one sentence within another using clause by showing the sentence that she wants to close the door. Kak aya as the subject that tells what is about, and tutup is the verb that tells what the subject is doing.

Azzura (Object 2):

Dialogue A:

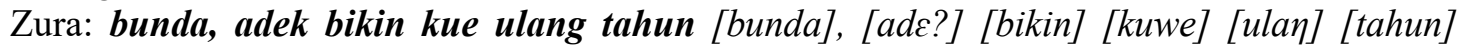
"mom, I'm making a birthday cake"

The dialogue above shows that Azzura is able to embed one sentence within another using clause by showing the sentence that she is making a birthday cake. Adek as the subject that tels what is about, and buat is the verb that tells what the subject is doing.

Dialogue B:

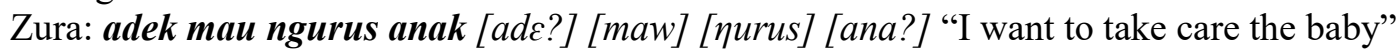

Kakak aya gausah [kaka?] [aya] [gausah] "you may not"

Zahra: ini juga [ini] [juga] "it is also"

Uti, bukain pintunya! [uti], [bukain] [pintuń]! "uti, open the door!"

The dialogue above shows that Azzura is able to embed one sentence within another using clause by showing the sentence that she wants to take care the baby. Adek as the subject that tells what is about, and ngurus is the verb that tells what the subject is doing.

Azzahra ( Object1):

Dialogue C:

Zahra: kita main kelatak setelah pulang dari sekolah ya dek [kita] [main] [kalata?]

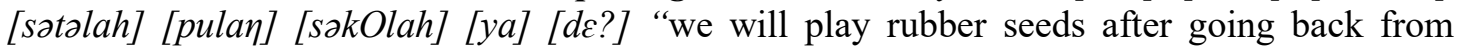
school"

Zura: adek mau jajan dulu kak [ade?] [maw] [jajan] [dulu] [ka?] "I want to buy some snacks" 
The dialogue above shows that Azzahra is able to embed on sentence within another using clause by showing that she explains to her younger sister about what she will do after going back from school.

Dialogue B:

Zura: jangan lama-lama mainnya ya kak [janan] [lamalama] [mainń] [ya] [ka?] "don't take too long to play"

Zahra: kakak aya mau makan saat udah selesai sholat nanti [kaka?] [aya] [maw] [makan] [saat] [udah] [salasai] [sholat] [nanti] "I want to eat when it has finished to pray"



The dialogue above shows that Azzahra is able to embed one sentence within another using clause by showing the sentence that she wants to do something after praying.

Dialogue C:

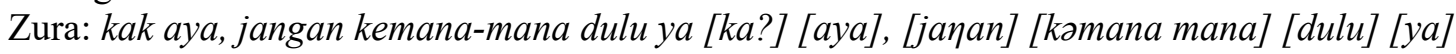
"kak aya, don't go anywhere!"

Zahra: kak aya mau beli makanan dulu karena kakak aya lapar [ka?] [aya] [maw] [boli] [makanan] [dulu] [karona] [kaka?] [aya] [lapar] "I want to buy some foods because I'm hungry"

Zura: adek ikut boleh kak? [adc?] [ikUt] [bolkh] [ka?]? "may I go with you?"

Zahra: boleh [bolch] "yes, you may"

The dialogue above shows that Azzahra is able to embed one sentence within another using clause when she said to her younger sister that she wants to buy some foods because she is hungry.

Dialogue D:

Bunda: kakak aya kita makan yok! [kaka?] [aya] [kita] [makan] [yo?] " let's eat!"

Zahra: kakak aya gak mau makan karena udah kenyang tadi

( I don't want to eat because I'm full)

The dialogue above shows that Azzahra is able to embed one sentence within another using clause by showing that she doesn't want to eat because she is full.

\begin{tabular}{|c|c|}
\hline Independent clause & Dependent clause \\
\hline Kita main kelatak & Setelah pulang dari sekolah ya dek \\
\hline Kakak aya mau makan & Saat udah selesai sholat nanti \\
\hline Kakak aya mau beli makanan & Karena kak aya lapar \\
\hline Kakak aya gak mau makan & Karena udah kenyang tadi \\
\hline
\end{tabular}

Azzura (Object 2):

Dialogue A: 
Zahra: dek, adek kenapa gak ikut keluar? [de?], [ade?] [kənapa] [ga?] [ikut] [kəluwar]? "why don't you play outside?"

Zura: adek gak mau keluar karena ada geluduk [ade?] [ga?] [maw] [kaluwar] [karcna] [ada] [galudu?] "I don't want because there is thunder"

The dialogue above shows that Azzura is able to embed one sentence within another using clause by showing the sentene that she doesn't want to go out because she is afraid of thunder.

Dialogue B:

Zura: adek punya mainan sejak beli jajanan yang tadi [ade?] [puń] [mainan] [saja?] [bəli] [jajanan] [yan] [tadi] "I got merchandise when I bought the snacks"

Zahra: kakak aya juga ada mainan ini, cantik lagi [kaka?] [aya] [juga] [ada] [mainan] [ini], [canti?] [lagi] "I also have a beautiful toy"

The dialogue above shows that Azzura is able to embed one sentence within another using clause. The dialogue happened when they went home from school and bought some snacks and get a toy inside the snacks.

Dialogue C:

Zahra: kakak aya gak dikasih keluar sama uti, dek [kaka?] [aya] [ga?] [dikasih] [kaluwar] [sama] [uti] [de?] "I amnot permitted to play outside"

Zura: iyala kakak aya gak dikasi keluar karena hujan deras tuh [iyalah] [kaka?] [aya] [ga?] [dikasi] [kaluwar] [karana] [hujan] [doras] [tuh] "of course, it is raining outside".

Dialogue D:

Zura: ih, kakak aya ini kokjahat kali! [ih], [kaka?] [aya] [ko?] [jahat] [kali]! "why you are so bad!"

Zahra: itu mainan kakak aya loo dek [itu] [mainan] [kaka?] [aya] [loo] [de?] "that's my toys!"

Zura: adek udah main ini sejak bangun tidur tadi kok [ade?] [udah] [main] [ini] [saja?] [bayun] [tidur] [tadi] [ko?] "I have been playing it since I woke up"

\begin{tabular}{|c|c|}
\hline Independent clause & Dependent clause \\
\hline Adek gak mau keluar & Karena ada geluduk \\
\hline Adek punya mainan & Sejak beli jajanan yang tadi \\
\hline Kakak aya gak dikasi keluar & Karena hujan deras tuh \\
\hline Adek udah main ini & Sejak bangun tidur tadi kok \\
\hline
\end{tabular}

Based on some dialogues above, it shows that Azzahra and Azzura are able to embed one sentence within another using clause.

\subsubsection{Use of preposition}

Preposition is a word (one of the parts of speech and a member of a closed word class) that shows the relationship between a noun or pronoun and other words in a sentence.

There are two functions of the preposition: 
1. To connect the noun to the rest of the sentence

2. Specify the position of the nouns( person or object)

There are basically 2 types of preposition:

1. Time preposition: time preposition are used to clarify the time of something that or someone of an action.

Examples: pada, sampai, selama, sejak, sebelum, sesudah, setelah

2. Place preposition: specify the place of someone or somebody.

Examples: di atas, di bawah, di depan, di belakang, diantara, di samping, dekat

Azzahra ( Object 1)

Dialogue A:

Zahra: doa ibu bapak sebelum ibu bapak dimulai [do'a] [ibu] [bapa?] [sabəlum] [ibu] [bapa?] [dimulai]"pray for parents before mom and father starts"

Zahra: apa nda? [apa] [nda]? "what's the matter, nda?"

The conversation is when they want to sleep, but before the were going to sleep they usually pray.

Dialogue B:

Bunda: sekolah kak aya dimana? [səkolah] [ka?] [aya] [dimana]?"where is your school?"

Zahra: sekolah kak aya dekat kuburan [sokolah] [ka?] [aya] [dokat] [kuburan] "my school is near from the graveyard"

Dialogue C:

Zahra: kita main kelatak setelah pulang dari sekolah ya dek [kita] [main] [kalatak] [satalah]

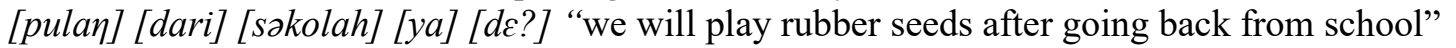
Zura: adek mau jajan dulu kak [ade?] [maw] [jajan] [dulu] [ka?] "I want to buy some snacks"

Dialogue D:

Zahra: kakak aya kan biasanya duduk di belakang bunda [kaka?] [aya] [kan] [biyasań]

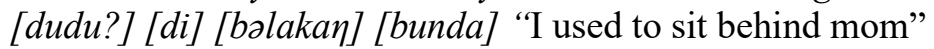

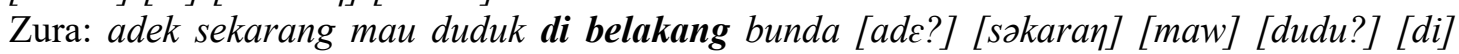

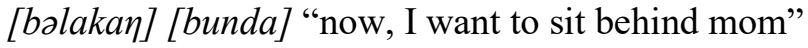

Zahra: kak aya gak mau gantian [ka?] [aya] [ni] [ga?] [maw] [gantiyan] "I don't want to turn with you"

Azzura (Object 2)

Dialogue A:

Zura: doa sebelum bobok dimulai. [do'a] [sabalum] [bobo?] [dimulai] "pray before sleeping starts"

\section{Bismillahirrahmaanirrahim.}

Bismika allahuma ahya wa amut aamiin.

Dialogue B: 
Bunda: adek mau bobok dimana? [ade?] [maw] [bobo?] [dimana]? "where do you want to sleep?"

Zura: adek mau bobok sebelah bunda [ade?] [maw] [bobo?] [sabalah] [bunda] 'I want to sleep beside bunda"

Dialogue C:

Zura: adek punya mainan sejak beli jajanan yang tadi [ade?] [puń] [mainan] [saja?] [bəli] [jajanan] [yan] [tadi] "I have toys since I bought the snacks"

Zahra: kakak aya juga ada mainan ini, cantik lagi [kaka?] [aya] [juga] [ada] [mainan] [ini], [canti?] [lagi] "I also have a beautiful toy"

Dialogue D:

Zura: ih, kakak aya ini kok jahat kali! [ih], [kaka?] [aya] [ko?] [jahat] [kali]! "why are you so bad!"

Zahra: itu mainan kakak aya loo dek [itu] [mainan] [kaka?] [aya] [loo] [de?] "that's my toys!"

Zura: adek udah main ini sejak bangun tidur tadi kok [ade?] [udah] [main] [ini] [saja?] [baqun] [tidur] [tadi] [ko?] "I have been playing it since I woke up"

The dialogue above shows that Azzahra and Azzura are able to use some kinds of prepositions to express something.

\subsubsection{Use of simple sentence}

Simple sentence is a sentence which contains one clause without bound clause.

A simple sentence usually contains subject, predicate and object.

3.1.7.1. Subject

Subject is who or what is doing or being something in the sentence. Take a simple sentence like 'Ahmad berlari'. The subject, the who of the sentence, is Ahmad. He's the one doing something.

\subsubsection{Predicate}

Predicate is the thing he or she is doing or being. The predicate is the verb of the sentence. Take a look at the sentence 'Kucing makan'. 'Makan' is the predicate of the sentence. This verb shows what is the cat doing.

4.1.7.3. Object

Object is the person or a thing upon whom or upon which the action of the verb is carried out. For example, 'Ayah mengendarai mobil'. In that sentence, the object is 'mobil'. Object is usually placed after predicate.

Azzahra ( Object 1)

Dialogue A:

Zahra: bunda, akung tadi main badminton [bunda], [akuך] [tadi] [main]

$\mathbf{S} \quad \mathbf{P} \quad \mathbf{O}$

[badminton] "bunda, akung played badminton" 
Zura: badminton? [badminton]? "badminton?"

Zahra: adek lebih lag i [ade?][labih][lagi] "adek is more"

Zura: lebih. Lebih.. lebih.. [labih] [labih] [labih]" more.. more..more.."

The conversation took place when their grandfather came home from playing badminton. And zahra said to her mother that her grandfather played badminton.

Dialogue B:

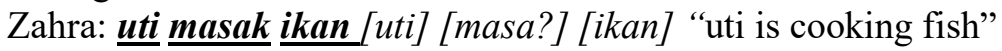

$$
\mathbf{S} \mathbf{P} \mathbf{O}
$$

Bunda: adek masak apa? [ade?] [masa?] [apa]? "what are you cooking, adek?"

Zura: masak telol [masa?] [talOl] "I'm cooking egg"

\begin{tabular}{|c|c|c|}
\hline SUBJECT & PREDICATE & OBJECT \\
\hline Akung & Main & Badminton \\
\hline Uti & Masak & Ikan \\
\hline
\end{tabular}

Azzura (Object 2)

Dialogue A:

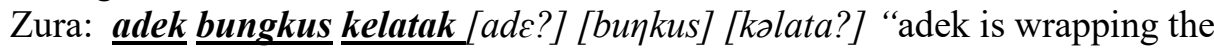
$S$

rubber seed

Dindin mau kelatak? [dindin] [maw] [kalata?]? "Do you want rubber seeds, dindin?"

Shila bungkus kelatak?[shila] [bunkus] [kalata?]? "Shila is wrapping the rubber seeds, aren't you?"

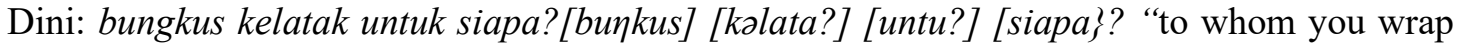
the rubber seeds?"

The conversation took place when she was playing the rubber seeds with her aunt.

Dialogue B:

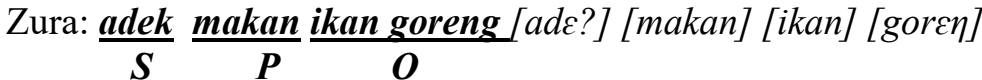

"I am eating fried fish"

Zahra: kakak aya makan ikan goreng juga [kaka?] [aya] [makan] [ikan] [goren] [juga] "So do I"

\begin{tabular}{|c|c|c|}
\hline SUBJECT & PREDICATE & OBJECT \\
\hline Adek & Bungkus & Kelatak \\
\hline Adek & Makan & Ikan goreng \\
\hline
\end{tabular}


The dialogue above between Azzahra with Azzura and Azzura with Dini her cousin, shows that the twin are able to use simple sentence in their speech.

\subsubsection{Use of overregularization}

Overregularization is a part of the language learning process in which children extend regular grammatical patterns to irregular words, such as the use of goed for went, or tooths for teeth. But, in Bahasa, there is no changing or the verb pattern from regular into irregular.

\subsubsection{Vocabulary}

Vocabulary refers to the words used in a language. The word vocabulary can have at least three different meanings. The first one is all the words in a language, the second is the words used in a particular context, and the last is the words an individual person knows.

To find how many vocabulary that the twin have, the writer do some technics to collect the data. The data is collected in one month. It is collected everyday by recording, listening, and writing the words that produced by the twin. The twin usually speaks with each other when they were playing. So that, the writer usually focus when they were playing, the twin will have many words produced. Not only when they were playing, the writer also asked the twin the things around them one by one. The writer would like to know whether the twin know the name of the things that the writer showed.

Based on the research, the writer finds that Azzahra the elder produces 1318 words while Azzura the younger produces 1335 words.

Based on the analysis and description above, the writer finds that some of the Kopp's theory regarding the language acquisition at sentence structure in three years old twin and it is shown by the following table:

\begin{tabular}{|l|l|l|l|}
\hline NO & CHARACTERISTIC & AZZAHRA & AZZURA \\
\hline 1 & Using yes/no questions & Applicable & Applicable \\
\hline 2 & Using why questions & Applicable & Applicable \\
\hline 3 & Using negative sentence & Applicable & Applicable \\
\hline 4 & Using imperative sentence & Applicable & Applicable \\
\hline 5 & $\begin{array}{l}\text { Embedding one sentence within } \\
\text { another using clause }\end{array}$ & Applicable & Applicable \\
\hline
\end{tabular}




\begin{tabular}{|l|l|l|l|}
\hline 6 & Use of preposition & Applicable & Applicable \\
\hline 7 & Use of simple sentence & Applicable & Applicable \\
\hline 8 & Use of overregularization & Unapplicable & Unapplicable \\
\hline 9 & $\begin{array}{l}\text { Vocabulary increases about 1000 } \\
\text { words }\end{array}$ & Applicable & Applicable \\
\hline
\end{tabular}

Figure 1. Result of Research

Based on the analysis, the writer finds that some characteristics are applicable to the both subjects. From, the nine characteristics of Kopp's theory, the writer finds that only one difference is found. The difference is the ability in mastery vocabulary. The first object, Azzahra has only 1318 words, and the second object, Azzura has 1335 words.

\section{Conclusion}

The results of this research is most of those characteristics from Kopp's theory do occur and applicable in acquiring form of sentence by three years old twin. From those nine characteristics, there is only one characteristic that the objects are not able to produce, that is using of overregularization. As the writer knows, overregularization is the changing in the verb pattern. In English, it is the pattern from present into past tense by using irregular verb and plural nouns. This pattern form does not occur in Bahasa Indonesia. In vocabulary acquisition, they have different number. Azzahra can utter 1318 words, Azzura can utter 1335 words.

\section{References}

[1] W. Wibowo, Manajemen Bahasa. Jakarta: Gramedia Pustaka Utama, 2001.

[2] Walija, Bahasa Indonesia dalam Perbincangan. Jakarta: IKIP Muhhamdiyah Jakarta Press, 1996.

[3] A. Chaer, Kajian Teoretik. Jakarta: Rineka Cipta, 2003.

[4] D. E. Papalia, Human Develpment, 7th ed. Boston: McGraw-Hill, 1998.

[5] Sugiono, Metode Penelitian Kualitatif dan Kuantitatif dan R\&D. Bandung: IKIP Muhhamdiyah Jakarta Press, 2008.

[6] M. Q. Patton, Qualitative Evaluation and Research Methods, 2nd ed. Newbury Park: SAGE, 1990.

[7] M. Nazir, Metode Penelitian. Jakarta: Ghalia Indonesia, 2011. 